\title{
The Influence of Indigenous Culture on Sport Psychology Practice: Challenges and Prospects
}

\author{
Hagan Jnr John Elvis ${ }^{1,2 *}$ and Schack Thomas ${ }^{1,2}$ \\ ${ }^{1}$ Faculty of Psychology and Sport Sciences, Bielefeld University, Germany \\ ${ }^{2}$ Cognitive Interaction Technology, Bielefeld University, Germany
}

Submission: November 09, 2017; Published: November 28, 2017

*Corresponding author: CHagan Jnr John Elvis, Faculty of Psychology and Sport Sciences, Bielefeld University, Germany, Email: elvis.hagan@ucc.edu.gh

\begin{abstract}
Given that contemporary cultural sport psychology has advocated for more inclusiveness involving intersecting cultural identities for applied work (research and practice), it is still surprising that information on indigenous practices across many societies remain untapped. This opinion paper highlights a range of issues that have been addressed within differing cultural contexts and offer ways in which indigenous practices could be integrated into existing professional frameworks across diverse societies that maintain respect for new set of culture-specific behavioral norms, beliefs and practices.
\end{abstract}

Keywords: Culture; Competence; Shamanism; Identities; Practice; Psychology

\section{Introduction}

The past decade has seen a consistent upsurge in literature regarding cultural diversity in sport and a continual demand for more culturally underpinned sport psychology research and practice [1]. The foundation of this emerging paradigm is the idea of cultural praxis, "a critical discourse" and "an attempt to broaden the epistemological spectrum of theory and practice in the field" [2]. This perspective contests deep-rooted cultural theories, research, and practice, and attempts a paradigm shift in the field of sport psychology from decontextualized knowledge to new approaches that consider athletes by their divergent backgrounds and identities [1]. One criticism that has often been raised against mainstream psychology by some researchers is its lack of openness to different cultures and its cultural one-sidedness [3]. Critiques as varied as eurocentrism [4], westocentrism [5], individuocentrism, irrelevance [6] and ethno centrism [7] are terms often used to describe these perceptions.

The necessity of these criticisms is based on the fact that culture permeates across many aspects of human functioning, such as patterns of language, thoughts, actions, customs, beliefs, courtesies, rituals, manners, interactions, roles, expected behaviors, and values connected with race and ethnicity [8]. However, recent developments suggest that varied socio-cultural differences exist across a wide spectrum of constructs in sport [9]. Some researchers in sport psychology have acknowledged cultural impact on dimensions as diverse as regulation of emotions [10], participation motives [11], athlete identity [12], attributions of success and failure [13], coping style [14], goal orientations [15], preferred coaching behaviors [16], social physique anxiety [17], and responses to athletic retirement [18]. Similarly, shamanism (i.e., concept behind traditional healing ceremonies) offers diverse practices to access different modes of consciousness to incorporate deeper brain activation for perception and cognitive processing within a healing process, a pathway that can be tapped for athletes' injury rehabilitation, motor control and action anticipation [19]. Furthermore, new technologies such as eye-tracking, neuro feedback, memory measurements may as well offer researchers and applied practitioners with better understanding towards cognitive functioning and the effects of indigenous practices from a scientific viewpoint [20].

The development of cultural competence opens another chapter that allows sport psychology practitioners to integrate athletes' and other analogous personnel compatible behaviors and attitudes that show culture and other socio-political factors mould individuals' behaviors that intertwine at several levels of professional practice $[1,8]$. It has been recommended that practitioners in sport psychology ought to formally seek knowledge of different cultures as well as make a commitment to be well informed about current prevailing issues in this area 
[8]. Another area that may require significant improvement is linguistic challenges [21] and objective measuring instruments [22]. Therefore, adopting a meaningful dialogue (communication) between athletes and practitioners through a shared language that promotes a shared experience would be worthwhile. A productive exchange of ideas opens sport psychology practitioners' communication channels to new perspectives of athletes' localized beliefs and values (e.g., customary rites, issues about religion and/ or spirituality) specific to their context. This open-minded approach to relevant information through dialogue helps develop a shared "cultural code" with specific elements unique to the local terrain towards professional practice [23].

The intricacy of these interrelated constructs (indigenous practices) in a typical socio-cultural context has led to the development of four key pointers for enhancing applied psychology work from typical western perspectives. Sport psychologists and other analogous practitioners would have to give precedence to the study of culturally distinct psychological and behavioral characteristics of the local people as well as examine the exact content and involved processes of these cultural related phenomena. Additionally, any research activity ought to integrate thoroughly the natural, tangible details of the phenomena to be investigated; and basing research on local intellectual local traditions rather than purely western approaches [24] These processes would help all involved with athletes deliver localized evidence-based interventions that uphold reverence for and consideration of cultural characteristics (e.g., spiritual beliefs, customary rites). For example, the "Haka", a customary postural dance used as pre-game ritual by New Zealand rugby representatives, could serve as a typical cue for other indigenous societies. This dance involves a combination of psyching verses, verbalizations, and primal scream. The "Haka" epitomizes New Zealand's cultural heritage that typifies bravery, resilience, assertiveness, determination, desire, confidence, and commitment. Sport psychologists, coaches, other personnel, and players have embraced, believed, observed this tradition over the years to their advantage during major competitions. By integrating, and adhering to similar traditional practices over time, athletes could optimize their pre-start state and potentially enhance future sports performance [22]. These indigenous practices may thus provide potential avenues for reconnecting nature with other conventional psychological techniques like imagery, relaxation, and self-talk [19]. By developing sport psychological practice through this cultural lens with advanced technologies could enrich sport psychologist-coach-athlete interactions toward athletes' well-being and performance enhancement $[1,2,20,22]$.

\section{References}

1. Ryba TV, Stambulova NB, Si G, Schinke R (2013) ISSP position stand: Culturally competent research and practice in sport and exercise psychology. International Journal of Sport and Exercise Psychology 11: 123-142.
2. Ryba TV, Wright HK (2010) Sport psychology and the cultural turn: Notes toward cultural praxis. In TV Ryba, RJ Schinke, G Tenenbaum (Eds.) The cultural turn in sport psychology, Morgantown, WV: Fitness Information Technology. (pp. 1- 28).

3. Louw J (2002) Psychology, history, and society. South African Journal of Psychology 32(1): 1-8.

4. Howitt D, Owusu-Bempah J, Owusu-Bempah K (1994) The racism of psychology: Time for change. Prentice Hall.

5. Holdstock TL (2000) Re-examining psychology: Critical perspectives and African insights. Psychology Press.

6. Berger S, Lazarus S (1987) The views of community organizers on the relevance of social practice in South Africa. Psychology in society 7: 6-23.

7. Kontos A, Breland-Noble AM (2002) Racial/ethnic diversity in applied sport psychology: A multicultural introduction with athletes of color. The Sport Psychologist 16: 296-315.

8. Schinke RJ, Moore ZE (2011) Culturally informed sport psychology: Introduction to the special issue. Journal of Clinical Sport Psychology 5 283-294.

9. Schinke RJ, Hanrahan SJ, Catina P (2009) Introduction to sport psychology. In RJ Schinke, SJ Hanrahan (Eds.) Cultural sport psychology Champaign Human Kinetics Illinois USA (pp. 3-12).

10. Mesquita B, Frijda NH (1992) Cultural variations in emotion: A review. Psychological Review 112: 179-204.

11. Kolt GS, Kirkby RJ, Bar-Eli M, Blumenstein B, Chadha NK (1999) A cross-cultural investigation of reasons for participation in gymnastics. International Journal of Sport Psychology 30: 381-398.

12. Schinke RJ, McGannon KR (2015) Cultural sport psychology and intersecting identities: An introduction in the special section. Psychology of Sport and Exercise 17 pp. 45-47.

13. Hallahan M, Lee F, Herzog T (1997) Its not just whether you win or lose its also where you play the game: A naturalistic cross-cultural examination of the positivity bias. Journal of Cross-Cultural Psychology 28: 768-778.

14. Ofori PK, Tod D, Lavallee D (2016) An exploratory investigation of superstitious behaviors, coping, control strategies, and personal control in Ghanaian and British student-athletes. International Journal of Sport and Exercise Psychology pp. 1-17.

15. Papaioannou AG (2006) Muslim and Christian students' goal orientations in school, sport, and life. International Journal of Sport and Exercise Psychology 4: 250-282.

16. Bolkiah S, Terry PC (2001) Coaching preferences of athletes in Brunei Darussalam and Great Britain: A cross-cultural test of the path-goal theory. In Papaioannou A, Goudas M, Theodorakis Y (Eds.) Proceedings of the International Society of Sport Psychology $10^{\text {th }}$ World Congress Thessaloniki Greece: Christodoulidi Publications (pp. 8-10).

17. Isogai H, Brewer BW, Cornelius AE, Komiya S, Tokunaga M et al. (2001) Cross-cultural validation of the Social Physique Anxiety Scale. International Journal of Sport Psychology 32: 76-87.

18.Stambulova N, Stephan Y, Jäphag (2007) Athletic re-tirement: A cross-national comparison of elite French and Swedish athletes. Psychology of Sport and Exercise 8: 101-118

19. Schack T, Schack E (2017) Anticipation in traditional healing ceremonies -The call from our past In M. Nadin (Eds.) Anticipation in medicine, Springer New York, USA, pp. 323-335.

20. Schack T, Bertollo M, Koester D, Maycock J, Essig K (2014) Technological advancements in sport psychology. In A Papaioannou, D Hackfort (Eds.) Routledge Companion to Sport and Exercise Psychology: Global 


\section{Psychology and Behavioral Science International Journal}

Perspectives and Fundamental Concepts London: Routledge (p. 953965).

21. Hanrahan SJ, Schinke, RJ (2011) Culture in sport psychology. In T. Morris, \& P. C. Terry (Eds.), The new sport and exercise psychology companion (pp.553-566). Morgantown, WV: Fitness Information Technology.

22. Hagan JE, Schack (2017) Integrating pre-game rituals and pre-performance routines in a culture-specific context: Implications for sport psychology consultancy. International Journal of Sport and Exercise Psychology 15(1): 1-14

23. Ryba TV (2009) Understanding your role in cultural sport psychology. In RJ Schinke, SJ Hanrahan (Eds.) Cultural sport psychology Champaign, Human Kinetics, Illinois, USA pp. 35-44.

24. Yang K (1997) Indigenizing westernized Chinese psychology. In MH Bond (Ed.) working at the interface of culture: Twenty lives in social science Routledge, London.

\section{Your next submission with Juniper Publishers will reach you the below assets}

- Quality Editorial service

- Swift Peer Review

- Reprints availability

- E-prints Service

- Manuscript Podcast for convenient understanding

- Global attainment for your research

- Manuscript accessibility in different formats

( Pdf, E-pub, Full Text, Audio)

- Unceasing customer service

Track the below URL for one-step submission https://juniperpublishers.com/online-submission.php 